\title{
Seismic Performance of a Hybrid Coupled Wall System Using different Coupling Beam Arrangements
}

\author{
Molham SALAMEH ${ }^{1}$ \\ Mohsenali SHAYANFAR ${ }^{2}$ \\ Mohammad Ali BARKHORDARI ${ }^{3}$
}

\begin{abstract}
:
This study implemented multi-record nonlinear dynamic and fragility analysis in order to gain better insight into the hybrid coupled wall (HCW) system. Two potentials are used to construct coupling beams, which are the typical steel coupling beam and the replaceable steel coupling beam. Furthermore, an innovative idea for replaceable beams is discussed using reinforced concrete infill instead of steel stiffeners. A new simplified FE model for such beams is carried out in order to explore how this new beam influences the seismic performance of $\mathrm{HCW}$ system. An additional equivalent bare RC wall case study is also taken into account for a comprehensive comparison. A precise $2 \mathrm{D}$ modelling method using OpenSees platform is adopted after validation against experimental and complex 3D numerical simulations. The results indicate a good effect of the replaceable coupling beams concept upon reducing the vulnerability of wall piers under low and moderate events. In terms of coupling beams fragility, the replaceable steel coupling beams also demonstrate better damage resistance when compared with typical steel beams under low and moderate seismic events. Using reinforced concrete infill instead of steel stiffeners can significantly protect beam maintenance without deteriorating wall piers vulnerability.
\end{abstract}

Keywords: Hybrid coupled wall (HCW), replaceable steel coupling beam (RSCB), replaceable composite coupling beam, nonlinear dynamic analysis, fragility assessment.

\section{INTRODUCTION}

Recent investigations have demonstrated that the modern buildings have good performance in terms of life safety. However, post-earthquake repair of buildings is costly and time

Note:

- This paper was received on August 19, 2020 and accepted for publication by the Editorial Board on April 9, 2021.

- Discussions on this paper will be accepted by November 30, 2022.

- https://doi.org/10.18400/tekderg.782642

1 Iran University of Science and Technology, School of Civil Engineering, Tehran, Iran molham_s188@yahoo.com - https://orcid.org/0000-0003-2871-0074

2 Iran University of Science and Technology, School of Civil Engineering, Tehran, Iran shayanfar@iust.ac.ir - https://orcid.org/0000-0001-6358-2771

3 Iran University of Science and Technology, School of Civil Engineering, Tehran, Iran barkhordar@iust.ac.ir - https://orcid.org/0000-0001-7760-0475 
consuming. Therefore, recent advances in structural engineering are more than ever oriented towards construction of economical and easily repairable earthquake-proof buildings. Use of hybrid coupled shear walls is one of these interesting systems which has gained attention over the past decade. It consists of two or more RC walls connected by means of steel or composite concrete-steel coupling beams. Much effort has been devoted to study the seismic behaviour of HCW systems [1-19]. Generally, since basic damage extent is substantially concentrated in the coupling beams, the latest research is oriented to make them replaceable after being damaged (e.g. Fortney et al. [20], Christopoulos and Montgomery [21] and Ji et al. [22]). Among them, the replaceable steel coupling beam (RSCB) (Fig. 1-a) seems to be the most practical. The RSCB constitutes of a "fuse" shear link connected at its two ends to steel beam segments which are supposed to remain elastic even under high lateral displacement demand. Appropriate link-to-beam connection produced by Ji. et al. [22] can permit easy replacement of the damaged shear link even when residual drifts exist. However, typical steel moment critical coupling beams (Fig. 1-b) can still be used in current projects because of easy construction. Ji. et al. [23] assessed the seismic performance of a HCW system with RSCBs against the traditional RCW with RC coupling beams. They concluded that the expected damage to the walls, even under extreme events, is limited to cracks and slight spalling of concrete. Moreover, the HCW system with RSCBs illustrates enhanced performance over the conventional RCW with RC coupling beams in terms of beams vulnerability. Herein a similar assessment is carried out to assess HCW system with RSCBs against HCW system with typical steel coupling beams. Furthermore, an innovative replaceable composite coupling beam method will be estimated. Coupling beams in such systems have a similar principle as the links of eccentrically braced frames (EBFs). Accordingly, they can be classified as long, intermediate and short links. According to Euro Code 8 [24] the steel link is classified as short link when the link length $\mathrm{e}<\mathrm{e}_{\mathrm{s}}=1,6$ $\mathrm{M}_{\mathrm{p}, \text { link }} / \mathrm{V}_{\mathrm{p}, \text { link }}$ and as long link when $\mathrm{e}>\mathrm{e}_{\mathrm{L}}=3,0 \mathrm{M}_{\mathrm{p}, \text { link }} / \mathrm{V}_{\mathrm{p} \text {,link }}$ where $\mathrm{M}_{\mathrm{p} \text {,link }}$ and $\mathrm{V}_{\mathrm{p} \text {, link }}$ are link design yielding bending and shear. When link length is between $\mathrm{e}_{\mathrm{s}}$ and $\mathrm{e}_{\mathrm{L}}$, it is classified as intermediate link. Recently, Ji et al. [25] produced the very short link type when web plate is made from lower yield strength than flanges, and $\mathrm{e} /\left(\mathrm{M}_{\mathrm{p}, \text { link }} / \mathrm{V}_{\mathrm{p} \text {,link }}\right)$ ratio is less than 1 . These links can provide very high inelastic ductility on the order of $0.14 \mathrm{rad}$ rather than $0.08 \mathrm{rad}$ which is stated by Euro Code 8 [24]. Furthermore, the over-strength factor of such links can reach 1.9 due to substantial participation of shear strength in flanges and high inelastic rotation capacity. This type of links has been adopted by Ji et al. [23] for RSCB method in HCW system. Whereas typical steel coupling beams are usually moment-critical elements and are classified as long links with an inelastic ductility which equals only 0.02 rad as stated by Euro Code 8 [24].

Using reinforced concrete infill instead of steel stiffeners has not yet been proposed in such fuse shear links. The details of this method are portrayed in Fig. 2, noting that the stirrups and the web of steel link are welded together in order to ensure safe transformation of shear forces between the web and concrete infill .There is a significant lack in the literature about this component performance when used as shear force resisting element. Composite link idea has originated in Technical University of Darmstadt in 1989 using an experimental program to assess the concrete infill efficiency to prevent web buckling rather than typical web stiffeners. Kanz et al. [26] produced an experimental study to estimate the behaviour of twostorey eccentrically braced composite frame. The results show that concrete infill with closely spaced stirrups is an effective replacement of steel stiffeners typically used in 
eccentrically braced frame system (EBFs). Shayanfar et al. [27] also studied composite shear link to be utilized in EBFs with vertical links (V-EBFs).The results reveal an increase in shear strength and dissipated energy up to 100 and 38 per cent, respectively over using steel link only.

This study aims to make quantitative fragility assessment of HCW system when using different schematic potentials to construct coupling beams as portrayed in Fig. 3. Case 1 is conventional RC wall which represents the most frequent system, and the easist to be construct. Case 2 represents using HCW system with typical steel coupling beams (TSCBs). Case 3 represents using HCW system with replaceable steel coupling beams (RSCBs). Case 4 represents using HCW system with a newly proposed type of links; this type includes using reinforced concrete infill instead of steel stiffeners in RSCB case. The new type can be called RCCBs (Replaceable Composite Coupling Beams). Using reinforced concrete infill instead of steel stiffeners may present some challenges in construction. Nevertheless, it may be chosen as a retrofitting or strengthening solution in order to dissipate seismic energy through concrete crushing. This will contribute to protecting the steel portion of the link from extra damage. It not only prevents buckling in web but also attains up to 2 times the shear capacity of bare steel link without affecting its initial stiffness. Since increasing initial stiffness of links will increase the seismic demand for the HCW system.

In this study a new simplified FE model for such link will also be carried out in order to explore how this new beam influences the seismic performance of HCW system. With a view to ease the ability to follow the text and figures, the following abbreviations will be used: $\mathrm{RC}$ wall, HCW-TSCB, HCW-RSCB and HCW-RCCB for Case 1, Case 2, Case 3 and Case 4, respectively.

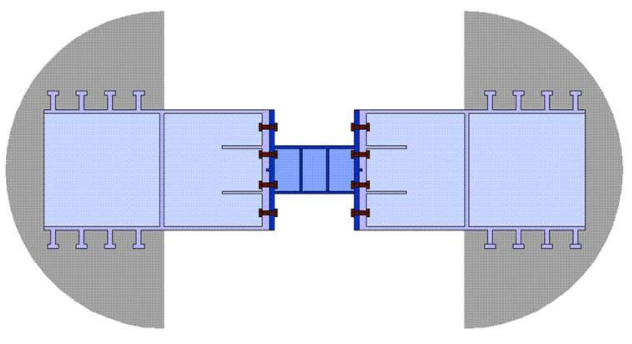

(a)

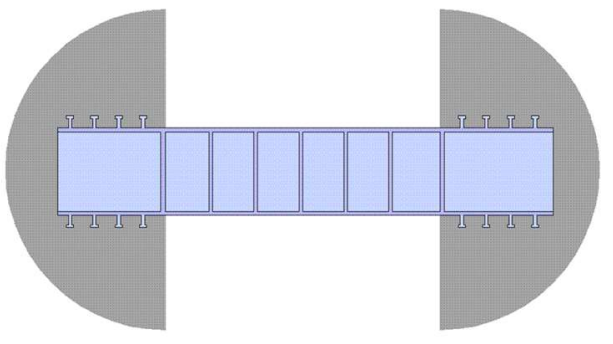

(b)

Fig. 1 - (a) Replaceable steel coupling beam (b) Typical steel coupling beam
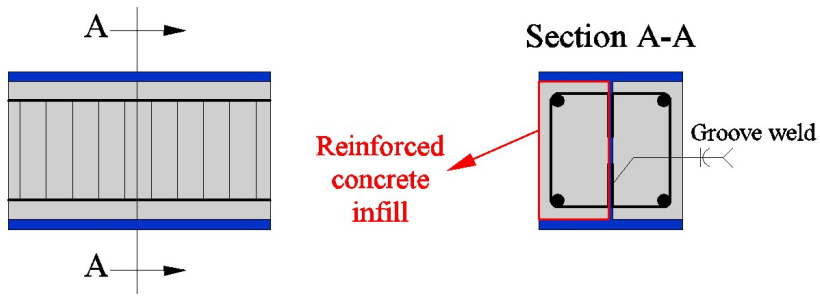

Fig. 2 - The details of using reinforced concrete infill in steel link 
Case 4: HCW-RCCB Case 3: HCW-RSCB Case 2: HCW-TSCB Case 1: RC wall

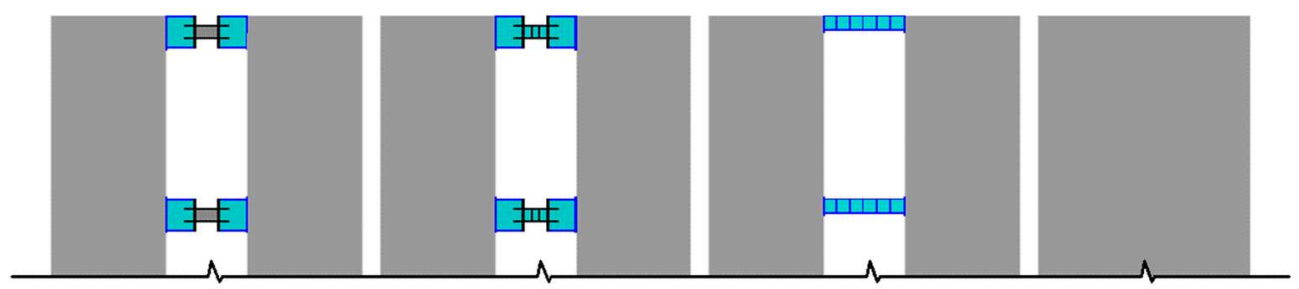

Fig. 3 - The case studies proposed for lateral force resisting system

\section{PROTOTYPE STRUCTURE:}

The prototype structure constitutes of a six-storey building; the plan is depicted in Fig. 4. The lateral resisting system is composed of four steel moment frames in the long direction and two HCW systems in the short direction. The short direction case is only considered in this study using a 2D model. Three case studies are selected to represent HCW system in addition to one case representing conventional $\mathrm{RC}$ wall system ( $\mathrm{RC}$ wall) as shown in Fig. 3. First, the building is designed using HCW-RSCB case according to Euro Code8 [24]. Ground type $\mathrm{A}$ and peak design acceleration $0.3 \mathrm{~g}$ in accordance with Euro Code 8 are considered with behaviour factor $q=3,3$. Dead load for all floors is assumed to be $4.4 \mathrm{kN} / \mathrm{m}^{2}$ and $3 \mathrm{kN} / \mathrm{m}^{2}$ for the roof. Live load for all floors is assumed to be $2 \mathrm{kN} / \mathrm{m}^{2}$ and $1.5 \mathrm{kN} / \mathrm{m}^{2}$ for the roof. The self-weight loads of structural elements are taken into account. The allowable drift checks are also verified according to Euro Code8 [24]. The wall pier details for all HCW cases are shown in Fig. 5-a. The original assumption is to implement similar coupling ratio for HCW-TSCB and HCW-RSCB cases. Coupling ratio (CR) is defined as the proportion of overturning moment resisted by coupling action over the overall system resistant moment stated as follows:

$C R=\frac{L \sum V_{\text {beam }}}{L \sum V_{\text {beam }}+\sum M_{w}}$

Where $\Sigma V_{\text {beam }}$ is the accumulation of the coupling beam shears acting at the edge of one wall pier; $\mathrm{L}$ is the lever arm between the centroids of the wall piers, and $\Sigma \mathrm{M}_{\mathrm{w}}$ is the total overturning moment resisted by the wall piers. Accordingly, given the same strength of wall piers and same distance between walls, both coupling beams of HCW-TSCB and HCWRSCB cases should give similar shear force resistance value at the ends in order to achieve the same CR ratio. El-Tawil and Kuenzli [7] recommend that the CR ranges from 30 percent to 45 percent for an efficient design. In this research, the HCW systems are conceived to have a CR equals 40 percent. The conventional shear wall system (RC-wall) is designed to have similar lateral strength and initial stiffness as HCW-RSCB, thus it has similar fundamental period as HCW-RSCB. RC-wall details are shown in Fig 5-b. The steel stiffeners of steel link are designed in accordance with Euro Code8 [24] guidelines with $10 \mathrm{~mm}$ thickness. In HCWRCCB, a high confined concrete fills the inner space of HCW-RSCB link instead of steel stiffeners. The inner reinforced concrete of this case is composed of (characteristic compressive strength $f_{c k}=25 \mathrm{MPa}$ ) concrete and (characteristic yield stress $f_{y k}=400 \mathrm{MPa}$ ) 


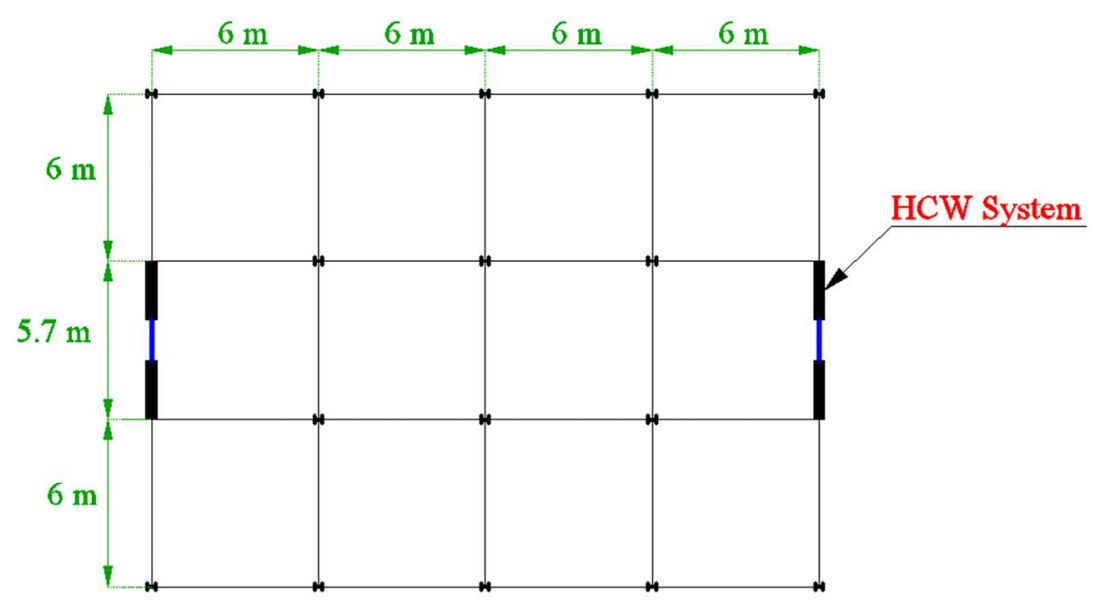

Fig. 4 - Plan configuration of the prototype structure

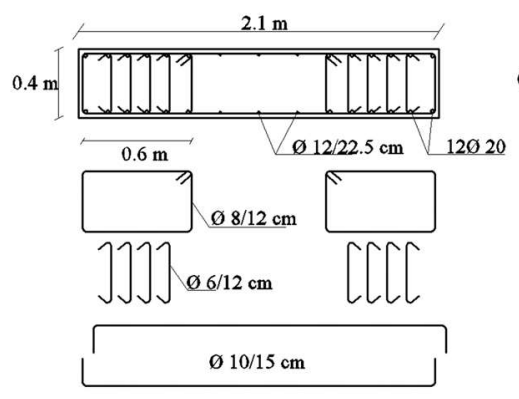

(a)

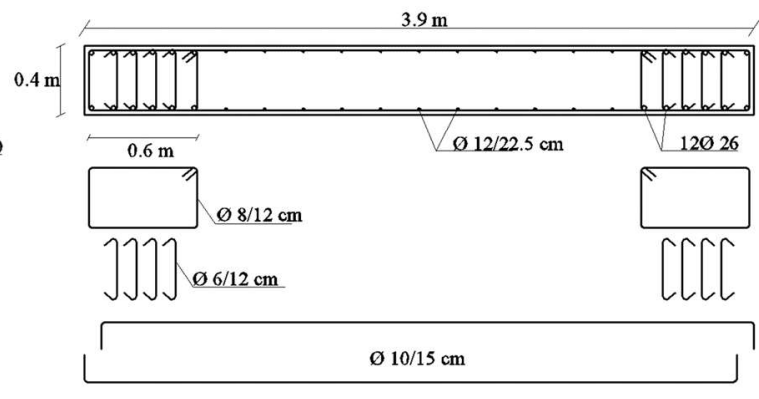

(b)

Fig. 5 - Arrangement of wall reinforcement: (a) Wall piers of HCW system (b) RC wall

for both longitudinal and transverse reinforcements. The coupling beam configurations used in this study are depicted in Fig. 6; and additional details of steel and composite links are portrayed in Fig. 7. The links of HCW-RSCB and HCW-RCCB have been previously tested by Shayanfar et al. [27] to be used in eccentrically braced frames. Based on Ji et al. [25], the links with a length ratio $e /\left(M_{\mathrm{p}} / V_{\mathrm{p}}\right)$ less than 1 are assumed to be classified as very short links with a maximum link angle rotation which equals $0.11 \mathrm{rad}$. Therefore, this value will be adopted for the links in HCW-RSCB. As consequence of the Shayanfar et al. [27] study, using steel profiles partially embedded in concrete does not affect rotation capacity of the original steel beam section. Thus, the same $0.11 \mathrm{rad}$ value is adopted as maximum rotation capacity for the composite link. The properties of utilized links and fundamental periods T1 for all cases are reported in Table1.The embedded profiles are designed to transfer maximum probable shear and moment forces resulting in the coupling links without exceeding the yielding limit. The embedded profiles are equipped with sufficient shear studs and can fulfil rigid connection with the wall. They are made of S355 steel $\left(f_{y}=355 \mathrm{MPa}\right)$. C30 concrete $\left(f_{c k}=30 \mathrm{MPa}\right)$ and $\mathrm{B} 450 \mathrm{C}$ reinforcements $\left(\mathrm{f}_{\mathrm{yk}}=450 \mathrm{MPa}\right)$ are used for concrete and rebars in 
all RC walls. Reinforcement bars are designed according to the DCM (medium ductility class) rules stated inEuro Code8 [24], Clause 5.4.3.4 for ductile walls. The link is connected to beam segments using the end-plate connection with high-strength bolts and shear keys. This connection is designed such that the shear force is resisted by shear keys and the bending moment is resisted by the bolts.

Table 1 - Fundamental periods and Coupling beams links properties

\begin{tabular}{|c|c|c|c|c|c|c|c|}
\hline & $\begin{array}{c}\mathrm{T} 1 \\
(\mathrm{sec})\end{array}$ & $\begin{array}{c}\text { Link } \\
\text { Length } \\
\text { (m) }\end{array}$ & $\begin{array}{l}\text { Link cross } \\
\text { section } \\
\text { (mm) }\end{array}$ & $\begin{array}{c}\text { Fy } \\
\text { (Flange,Web) } \\
\text { (Mpa) }\end{array}$ & $e /\left(M_{\mathrm{p}} / V_{\mathrm{p}}\right)$ & $\begin{array}{l}\text { Link } \\
\text { classificat- } \\
\quad \text { ion }\end{array}$ & $\begin{array}{c}\text { Max } \\
\text { angle } \\
\text { rotation } \\
\text { (rad) }\end{array}$ \\
\hline RC wall & 0.687 & - & - & - & - & - & - \\
\hline $\begin{array}{l}\text { HCW- } \\
\text { TSCB }\end{array}$ & 0.91 & 1.5 & IPE $270 \mathrm{O}$ & $(275,275)$ & 3.91 & Long & 0.02 \\
\hline $\begin{array}{l}\text { HCW- } \\
\text { RSCB }\end{array}$ & 0.688 & 0.4 & $\begin{array}{c}\text { Built up } \\
(240,6,220,15)\end{array}$ & $(300,249)$ & 0.35 & $\begin{array}{l}\text { Very } \\
\text { Short }\end{array}$ & 0.11 \\
\hline $\begin{array}{l}\text { HCW- } \\
\text { RCCB }\end{array}$ & 0.67 & 0.4 & $\begin{array}{l}\text { Built up } \\
(240,6,220,15) \\
+ \text { RC infill }\end{array}$ & $(300,249)$ & 0.68 & $\begin{array}{l}\text { Very } \\
\text { Short }\end{array}$ & 0.11 \\
\hline
\end{tabular}

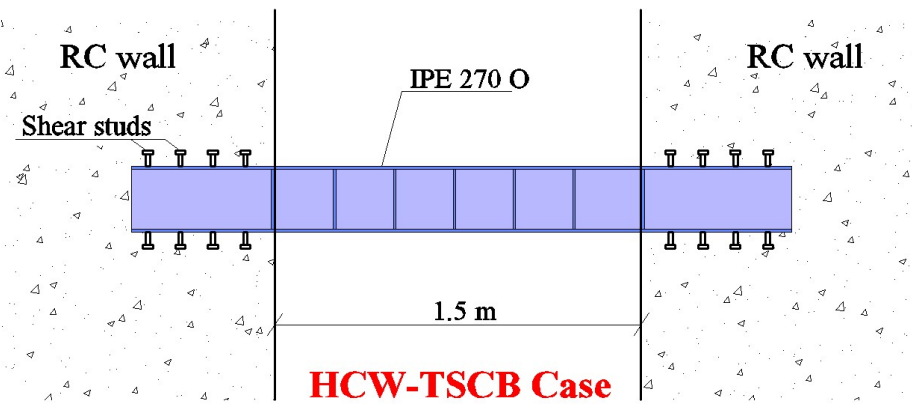

(a)

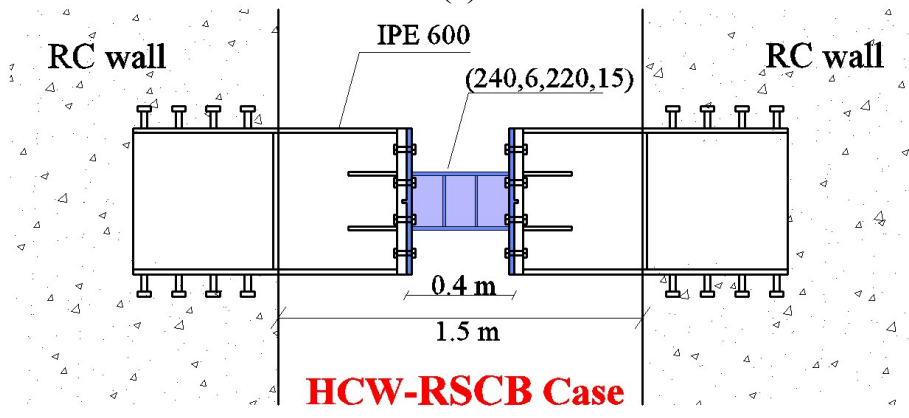

(b)

Fig. 6 - Adopted coupling beams configurations: (a) Typical steel coupling beam (HCWTSCB), (b) Replaceable steel coupling beam RSCB (HCW-RSCB), (c) Replaceable composite coupling beam RCCB (HCW-RCCB) 


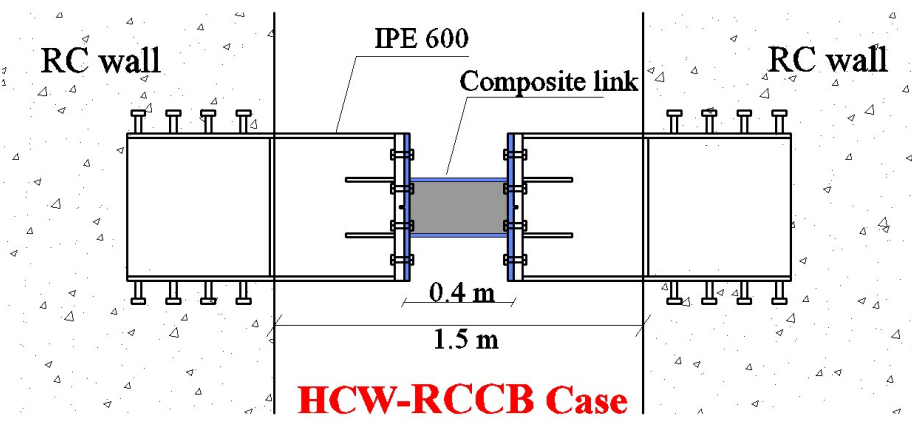

(c)

Fig. 6 (Cont.) - Adopted coupling beams configurations: (a) Typical steel coupling beam (HCW-TSCB), (b) Replaceable steel coupling beam RSCB (HCW-RSCB), (c) Replaceable composite coupling beam RCCB (HCW-RCCB)

Section A-A
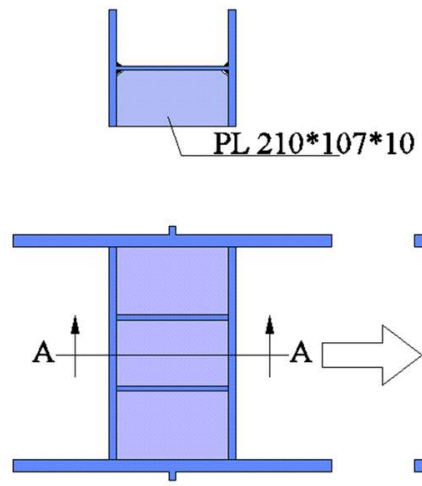

(a)
Section B-B
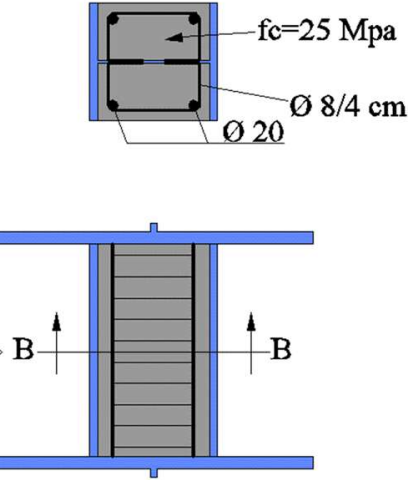

(b)

Fig. 7 - Arrangement of: (a) Steel link of HCW-RSCB, (b) Composite link of HCW-RCCB

\section{NUMERICAL MODEL SPECIFICATIONS}

\subsection{Steel Coupling Beams Modelling:}

The frame model with lumped plasticity model proposed by Bosco et al. [28] will be adopted to represent the steel coupling link. This model is derived from the elasto-plastic model introduced by Zona and Dall'Asta [29] and implemented in OpenSees software [30]. The schematic shape of this model is illustrated in Fig. 8-a. The elasto-plastic model presented by Zona and Dall'Asta [29] needs the following parameters: initial stiffness, yielding force, maximum force for asymptotically fully developed hardening, post-elastic stiffness, elasticto-plastic transition shape parameter $\alpha$, hardening rate parameter $\delta$ r. The initial stiffness $\mathrm{k}_{0}$, yield and maximum flexural and shear forces are obtained from the cross section properties of the link. The other parameters are calibrated based on experimental responses and three- 
dimensional finite-element simulations. The steel link used in HCW-RSCB is experimentally studied by Shayanfar et al. [27] to be used in EBF system. It will be used for the elasticplastic OpenSees model validation due to displacement history shown in Fig. 8-b. The results indicate a very acceptable performance with OpenSees model as shown in Fig. 9. Guiding lines are used in order to indicate the initial stiffness for each case. The initial stiffness of this model will be rearranged in order to accommodate the real behaviour of the link which is investigated in this study. However, by applying a simple sub-study using nonlinear pushover analysis and eigenvalue analysis, it could be easily concluded that even the high variation in link initial stiffness value (up to 30 percent) cannot make a substantial effect in structure response. For the long link type representing the HCW-TSCB case, there are no experimental investigations. Therefore, a complex 3D numerical simulations will be carried out using Abaqus software[31] in order to validate OpenSees modelling of this case due to displacement history shown in Fig. 8-b. The results indicate very acceptable performance as shown in Fig. 10.

The link resistance is terminated in the model when its rotation exceeds the allowed values reported in Table 1. This procedure represents the actual response of the system under extreme seismic events. Hence, once a link fails, the shear force will be redistributed among the rest of the links.

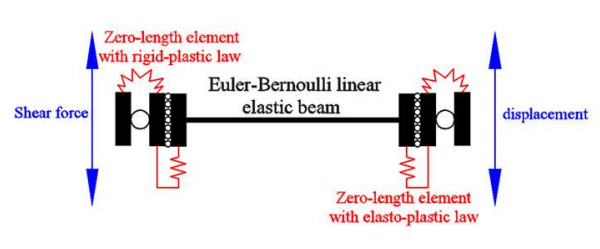

(a)

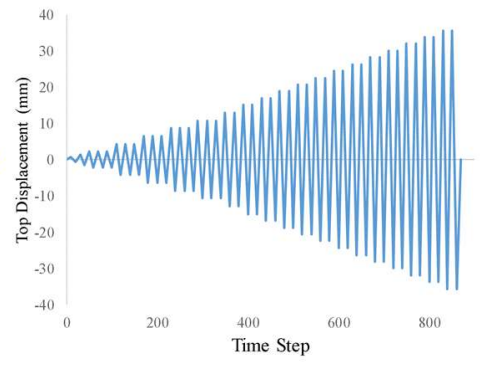

(b)

Fig. 8 - (a) Frame element model of the steel link (b) Displacement history

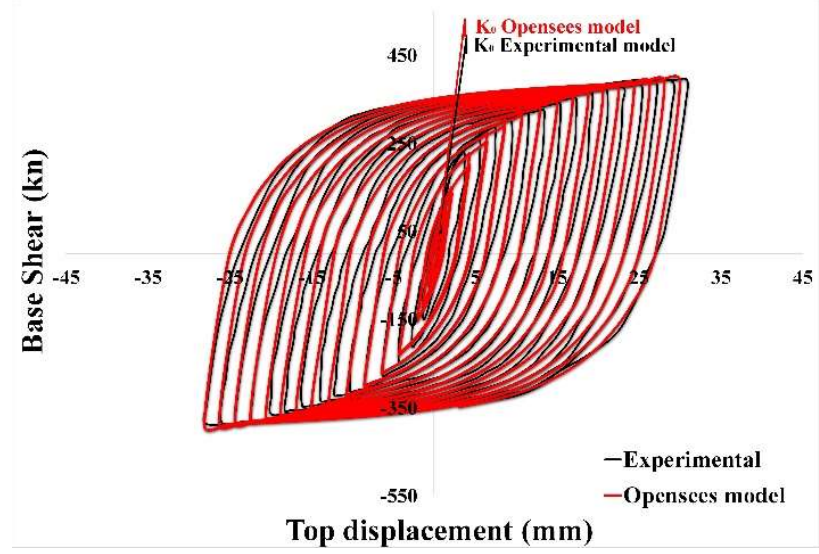

Fig. 9 - Comparison between the responses of experimental test and simplified FE model for the steel link of HCW-RSCB case 


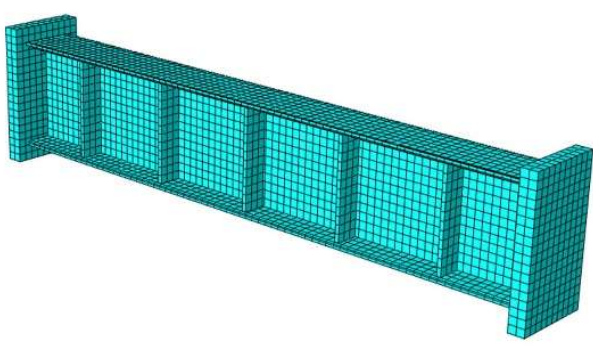

(a)

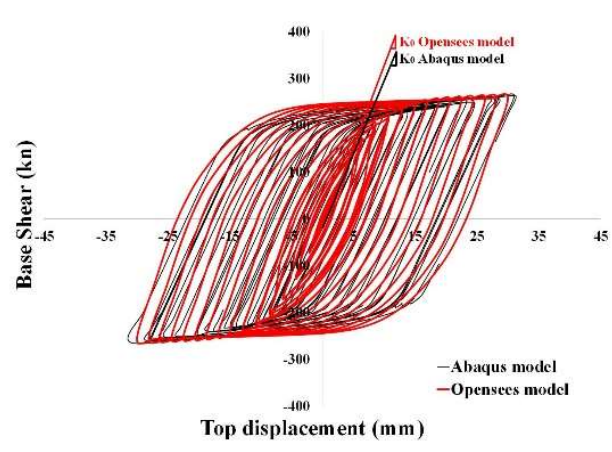

(b)

Fig. 10 - Link of HCW-TSCB case (a) ABAQUS simulation (b) Comparison between the responses of ABAQUS model and simplified FE model

\subsection{Composite Coupling Beams Modelling}

Steel profiles partially embedded in concrete are usually used in columns and rarely in beams. There is a lack of investigations concerned with using such components to serve as shear critical elements. Therefore, there is no finite element model in the literature to represent such elements so far. However, in order to estimate the effect of such element in HCW system, a correct model is extremely needed. Here, the attempt is done to create rational simplified model, taking advantage of similar structures concept such as (concrete-filled steel moment frame)[32] and (composite panel zone in composite moment frames)[33]. By observing the experimental results of the Shayanfar et al.[27] test program, it can be concluded that the final behaviour of the composite link is simply a contribution of the bare steel link and the confined concrete segment. The steel link can be presented by the Bosco et al. [28] model without considering moment behaviour to enhance the stability of the model analysis. This assumption could be accepted since the model behaviour will be governed by shear force as the e/( $\left.\mathrm{M}_{\mathrm{p}} / \mathrm{V}_{\mathrm{p}}\right)$ ratio is much lower than 1.6, and the steel link will not experience plastic yielding under moment. Based on the experimental test of this link [27], the results show diagonal cracks in concrete with inclination at approximately 30 degrees, which indicates the main direction of concrete strut efficiency. Therefore, firstly two pinned stiff elastic elements should be modelled to represent the flanges restriction of concrete strut without impacting the shear capacity. The second step is to determine concrete strut dimensions. For this purpose, the inner concrete is divided into three regions: unconfined, partially confined and highly confined concrete as presented in Fig. 11-a. Concrete02 material is used to represent strut concrete. The stress-strain relation of concrete is described using Mander et al. [34], Denavit et al. [35] and Paulay et al. [36] studies. Afterwards, an equivalent highly confined concrete cross section is adopted to express a unified behaviour of internal concrete Fig. 11-b. The two sides of concrete parts are assembled to express first the concrete strut dimension. To conclude the second strut dimension, the inner concrete compression strut relations of composite panel zone reported by ASCE Task Committee [33] are used in this case boundary conditions. It is concluded 
Seismic Performance of a Hybrid Coupled Wall System Using different Coupling ...

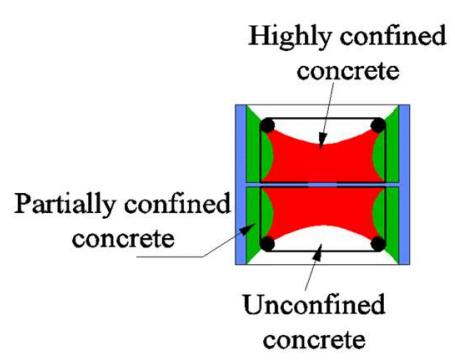

(a)

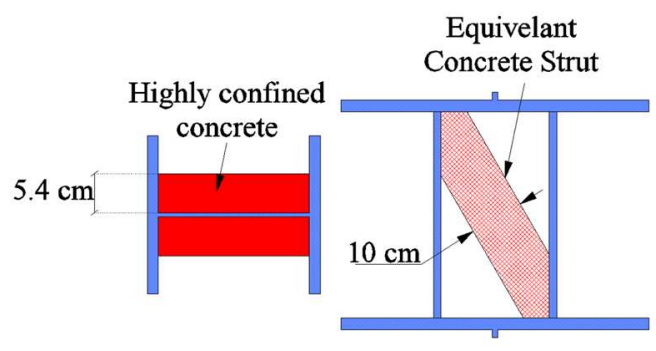

(b)

Fig. 11 - (a) The confinement zones, (b) Concrete Strut dimensions

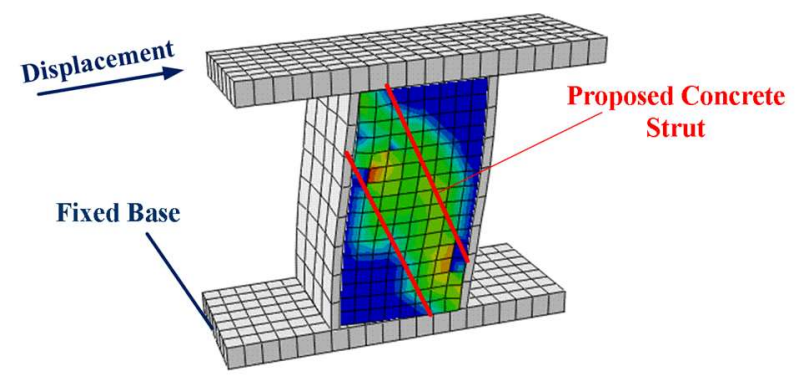

Fig. 12 - ABAQUS simulation of the composite link case and compression damage contours of the inner concrete

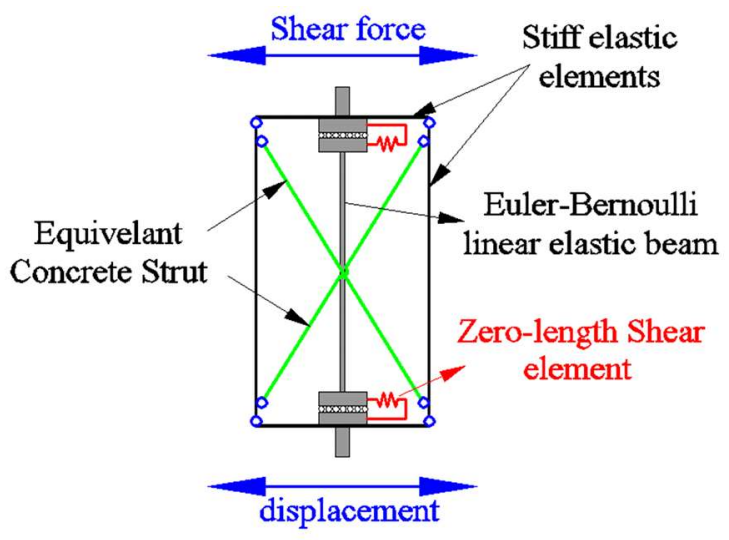

Fig. 13 - Proposed simplified finite element model of composite link 
that the strut width equals approximately one quarter of strut length value. In order to assure this conclusion, a refined Abaqus model of the composite link is carried out; Fig. 12 shows the contours of compression damage in concrete. It indicates good agreement with the calculated value of strut width as well as the inclination angle shown in the empirical observations. The displacement-based distributed-plasticity fibre frame element available in OpenSees is used to describe the axial behaviour of concrete struts. Finally, the proposed resulted model (Fig. 13) is validated against experimental hysteresis diagram presented by Shayanfar et al [27] investigation as shown in Fig. 14. It illustrates sufficient reliance to be utilized in final HCW system model. The initial stiffness value of this model is rearranged in order to accommodate the real behaviour of a coupling beam which is investigated in this study.

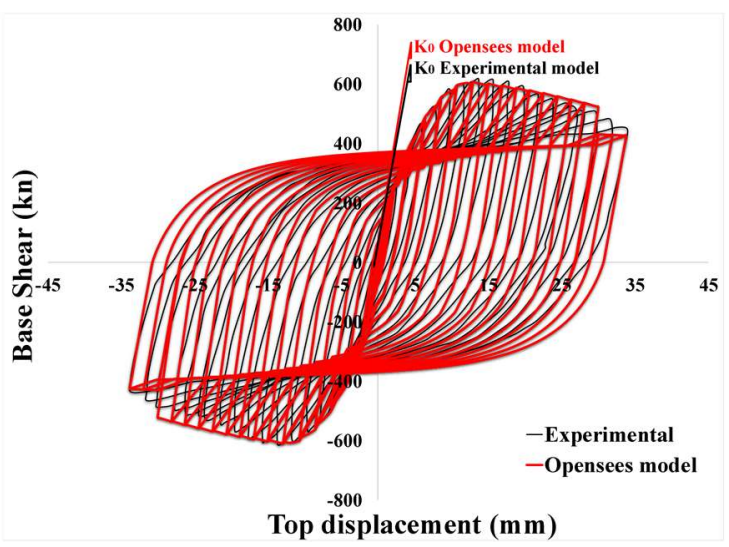

Fig. 14 - Comparison between the responses of experimental test and simplified FE model for the composite link of $H C W-R C C B$ case

\subsection{Modelling of RC Wall and HCW Systems:}

Multi-layered shell element is selected to express the RC shear walls. This method has been previously verified by Lu. et al. [37] and Ji. et al. [38]. The results indicate highly acceptable agreement with the experimental response. Lu et al. [37] applied it in OpenSees program. Concrete is represented by multi-layered elements, Fig. 15a[37]. The damage mechanics concept and fixed smeared crack model are the basis of the nonlinearity of the concrete in a plane stress state of the multi-layered model. The confined concrete at boundary elements is represented by the Saatcioglu-Razvi model [39]. Kent-Park model [40] defines the uniaxial stress-strain of unconfined concrete relation. The Giuffre-Menegotto-Pinto steel model [41] represents the uniaxial stress-strain relation for structural steel and rebars. The truss elements represent the longitudinal rebars in boundary elements. Equivalent smeared rebar layers in vertical and horizontal directions define the internal longitudinal and horizontal reinforcement, Fig. 15b[37].The embedded beam elements are designed to remain elastic under earthquake, thus they are modelled by elastic column-beam element produced by OpenSees. A zero-length shear element should be set between the link and the embedded beam elements as shown in Fig. 16 to represent elastic shear stiffness which equals $\mathrm{GA}_{\mathrm{w}} / \mathrm{l}_{\mathrm{b}}$; where $G$ represents shear modulus and $A_{w}, l_{b}$ denote web area and length of the expanded 
beam, respectively [23]. Rayleigh damping model for the first and second vibration modes is used in analysis with a damping ratio of 5 percent. A gravity column is modelled in order to assign superimposed permanent live and dead loads of each floor. It is joined to the original system using pinned rigid beams. Self-weight mass is lumped at both ends of each element.

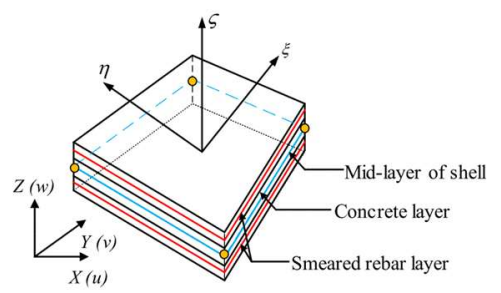

(a)

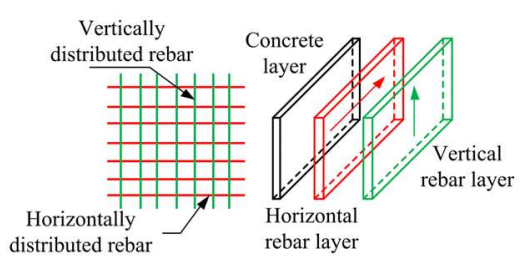

(b)

Fig. 15 - Sketch of multi-layer shell element for RC wall (Lu et al. [37])

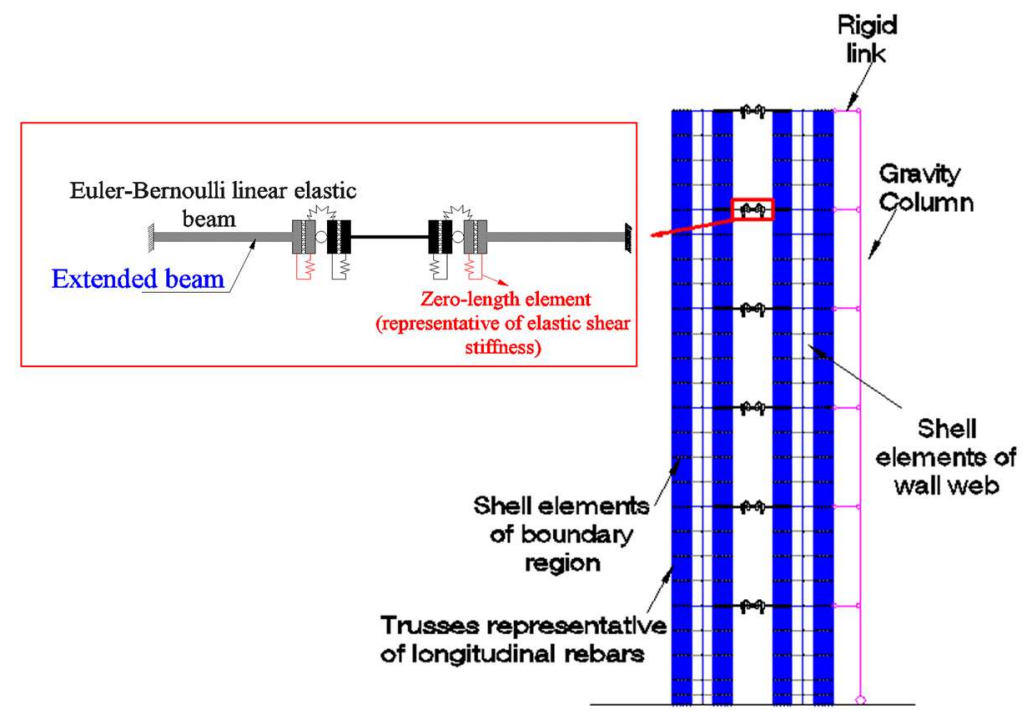

Fig. 16 - Finite element modelling for HCW system with replaceable steel coupling beam (HCW-RSCB case)

\section{NONLINEAR DYNAMIC ANALYSIS AT VARIOUS TARGET SPECTRA}

A set of 30 natural ground motion records are chosen using Pacific Earthquake Engineering Research (PEER) NGA database [42] with far-field type in accordance with soil type A. These records are scaled to fit in average the Euro Code 8 elastic spectrum with ground acceleration $0.3 \mathrm{~g}$ and soil type A. These ground motions are provided in Table 2.

Three levels of ground motion intensities are adopted to study the dynamic response of prototype structures. The first is representing DBE design basis earthquake level with 10 percent probability of exceedance in 50 years and a return period equal to 475 years. The 
second is computed for ground motion earthquake with 2 percent probability of exceedance in 50 years and a return period equal to 2475 years. The third is computed for ground motion earthquake with a 0.5 percent probability of exceedance in 50 years and a return period equal to 9975 years. The last two levels are estimated based on Euro Code 8 recommendation paragraph 3.2.1 (3)P [24] to represent maximum credible earthquake MCE and very rare earthquake VRE. Fig. 17 shows acceleration response spectra of the adopted 30 records with geometric mean and the target spectra of the three levels of ground motion intensities.

Table 2 - The ground motions utilized in nonlinear dynamic analysis

\begin{tabular}{|c|c|c|c|c|c|}
\hline No. & Event & Year & Station & $M w$ & $\operatorname{PGA}(g)$ \\
\hline 1 & San Fernando & 1971 & Cedar Springs_Allen Ranch & 6.61 & 0.32 \\
\hline 2 & Loma Prieta & 1989 & Piedmont Jr High School Grounds & 6.93 & 0.34 \\
\hline 3 & Loma Prieta & 1989 & SF - Rincon Hill & 6.93 & 0.32 \\
\hline 4 & Loma Prieta & 1989 & So. San Francisco_Sierra Pt. & 6.93 & 0.24 \\
\hline 5 & Chi-Chi_Taiwan & 1999 & TTN042 & 7.62 & 0.26 \\
\hline 6 & Chi-Chi_Taiwan-03 & 1999 & TCU085 & 6.2 & 0.25 \\
\hline 7 & Chi-Chi_Taiwan-03 & 1999 & TTN042 & 6.2 & 0.32 \\
\hline 8 & Chi-Chi_Taiwan-04 & 1999 & HWA002 & 6.2 & 0.24 \\
\hline 9 & Chi-Chi_Taiwan-04 & 1999 & TTN042 & 6.2 & 0.32 \\
\hline 10 & Chi-Chi_Taiwan-05 & 1999 & HWA002 & 6.2 & 0.34 \\
\hline 11 & Chi-Chi_Taiwan-05 & 1999 & ILA015 & 6.2 & 0.36 \\
\hline 12 & Chi-Chi_Taiwan-05 & 1999 & TAP075 & 6.2 & 0.28 \\
\hline 13 & Chi-Chi_Taiwan-05 & 1999 & TAP086 & 6.2 & 0.34 \\
\hline 14 & Chi-Chi_Taiwan-05 & 1999 & TTN042 & 6.2 & 0.44 \\
\hline 15 & Chi-Chi_Taiwan-06 & 1999 & CHY102 & 6.3 & 0.34 \\
\hline 16 & Chi-Chi_Taiwan-06 & 1999 & ILA015 & 6.3 & 0.26 \\
\hline 17 & Chi-Chi_Taiwan-06 & 1999 & ILA063 & 6.3 & 0.39 \\
\hline 18 & Chi-Chi_Taiwan-06 & 1999 & TAP086 & 6.3 & 0.26 \\
\hline 19 & Chi-Chi_Taiwan-06 & 1999 & TCU085 & 6.3 & 0.31 \\
\hline 20 & Chi-Chi_Taiwan-06 & 1999 & TTN042 & 6.3 & 0.26 \\
\hline 21 & Tottori_Japan & 2000 & HYG004 & 6.61 & 0.33 \\
\hline 22 & Chuetsu-oki_Japan & 2007 & FKSH15 & 6.8 & 0.43 \\
\hline 23 & Chuetsu-oki_Japan & 2007 & NGN013 & 6.8 & 0.41 \\
\hline 24 & El Mayor-Cucapah_Mexico & 2010 & El Monte County Park & 7.2 & 0.54 \\
\hline 25 & El Mayor-Cucapah_Mexico & 2010 & San Diego Road Dept & 7.2 & 0.36 \\
\hline 26 & Tottori_Japan & 2000 & KOC008 & 6.61 & 0.59 \\
\hline 27 & Tottori_Japan & 2000 & KYT005 & 6.61 & 0.25 \\
\hline 28 & Tottori_Japan & 2000 & SMN013 & 6.61 & 0.34 \\
\hline 29 & Niigata_Japan & 2004 & FKSH15 & 6.63 & 0.45 \\
\hline 30 & Niigata_Japan & 2004 & YMTH03 & 6.63 & 0.40 \\
\hline
\end{tabular}




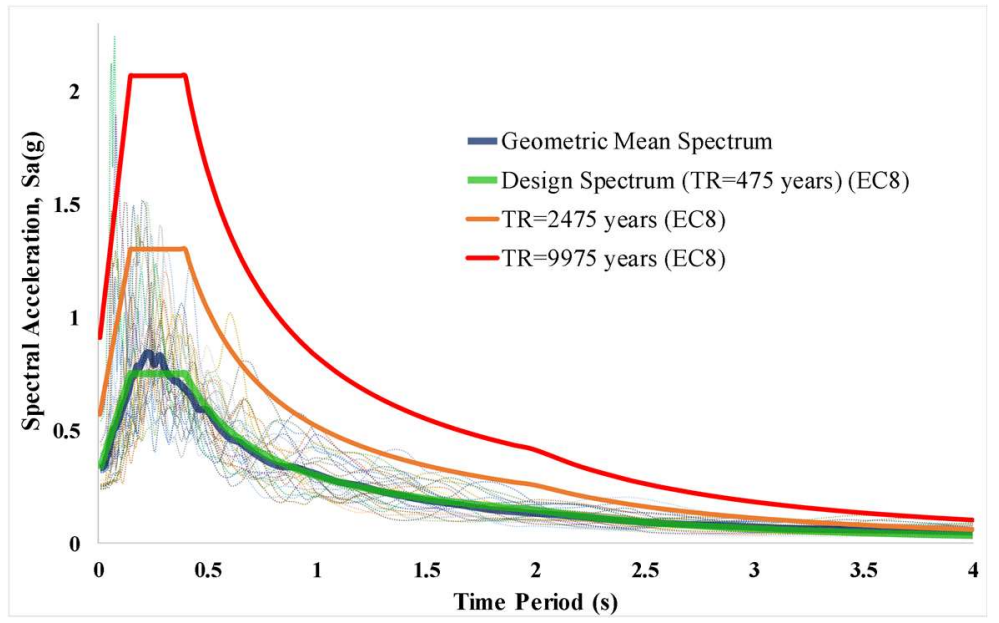

Fig. 17 - Target spectra and response spectra of the 30 scaled ground motion records

The maximum responses for each accelerogram are defined, then the mean values of the responses are presented. The lateral displacements, inter-storey drifts and links rotations normalized with respect to rotation capacity values are provided in Fig. 18 for the three earthquake intensity levels. Taking into consideration the analysis results, the conclusions below can be derived:

- Under TR=475 years (intensity level DBE), using replaceable steel and composite beams shows relatively similar lateral displacement demand. In the case of composite coupling beams, the inter-storey drifts tend to be uniform. In terms of links rotations, composite links demonstrate considerably lower rotation demand than the steel links with minimal values in the last storey. In comparison with typical steel coupling beam case, the inter-storey drift in the last storey of composite links case attains a reduction of 28 percent, and steel links case attains 25 percent reduction. Despite the high stiffness of the conventional wall system, all cases can achieve lower inter-storey drifts because of the high energy dissipation of HCW systems compared with bare RC wall system.

- Under TR=2475 years (intensity level MCE), both steel and composite links cases show similar behaviour. In comparison with typical steel coupling beam case, the inter-storey drift in the last storey of composite links case attains 15.4 percent reduction, and steel links case attains 13.8 percent reduction. In terms of links rotations, composite links still demonstrate lower rotation demand than the bare steel links with minimal values in the last storey.

- Under TR= 9975 years (intensity level VRE), all cases indicate similar displacement demand. It is worth mentioning that rotation demand values of the three cases are still lower than their rotation capacities.

For the purpose of estimating the seismic demand of the case studies, an incremental dynamic analysis (IDA) using (Base shear- $\mathrm{Sa}(\mathrm{T} 1)$ ) relation is performed for each record then the mean values are depicted in Fig. 19. The range of $S_{a}(T 1)$ scaling factors used in IDA analysis is from 0.02 to 1.3 with 0.03 interval value. Such analysis can illustrate the seismic force 
demand of each case. This will provide indications of required shear and flexural reinforcements as well as substructures design complications such as designing of foundations against uplift which is considered a quite perilous issue in such kind of systems.
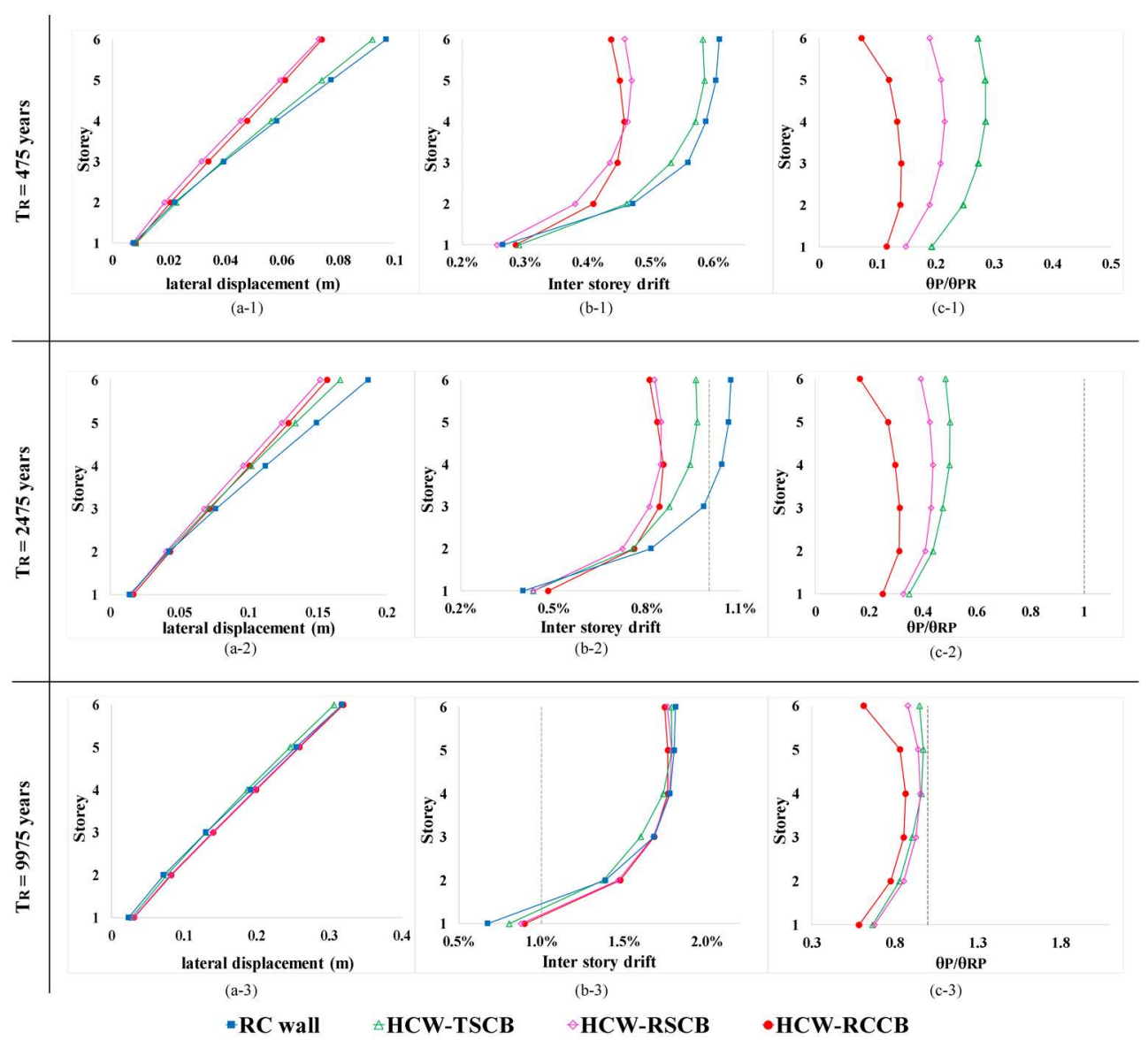

Fig. 18 - Mean over 30 accelerograms for all case studies (a) Lateral displacement (b) Inter-storey drifts (c) Links rotation demand normalized with respect to links rotation capacity

The vertical lines shown in Fig. 19 demonstrate the values of spectral accelerations at fundamental periods of each case. These lines are presented for the three seismic intensity levels illustrated previously. HCW-TSCB always has the lowest spectral acceleration value because it has the highest fundamental period among the case studies.

The results show that seismic demand values under DBE level for all cases are approximately comparable. Under extreme events (MCE and VRE levels), it should be noted that RC wall 
system demonstrates the highest seismic demand values while the typical coupling beam case shows the lowest ones. It is worth noting that despite the large shear force capacity shown by composite links, the seismic demand of HCW-RCCB has values close to the bare steel link case (HCW-RSCB) values under DBE and MCE levels; and smaller values than HCW-RSCB case under VRE level. This indicates that using composite links method will not require extra design detailing for wall piers and foundations.

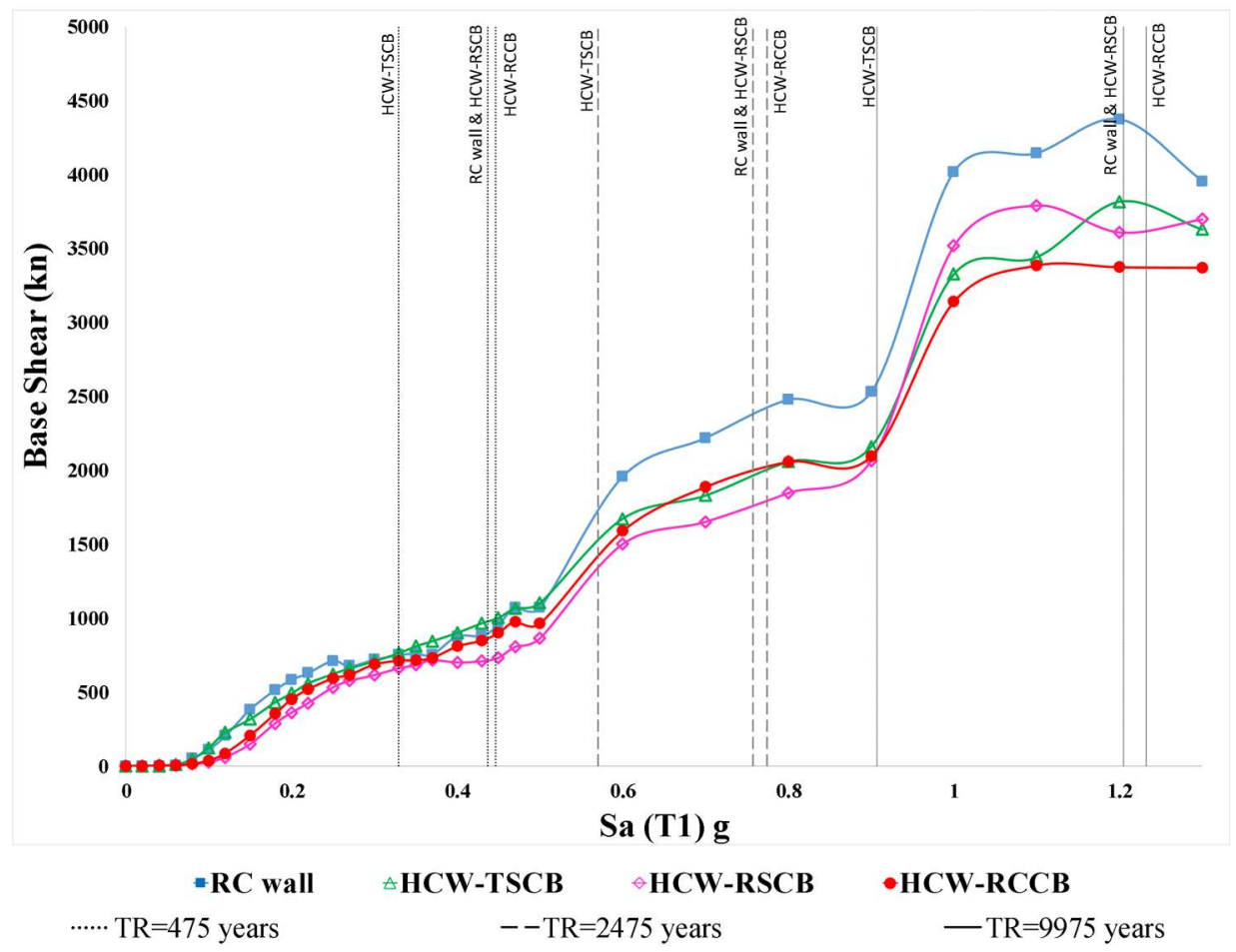

Fig. 19 - Mean over 30 accelerograms for nonlinear incremental dynamic analysis (IDA)

With a view to further explore the seismic performance of case studies, the mean residual storey drifts are reported in Table 3. Based on FEMA P-58 [43] recommendation, 0.2 percent expresses the limit value of residual storey drift below which no structural realignment is necessary for structural stability (however, the building may require adjustment and repairs to non-structural and mechanical components that are sensitive to building alignment (e.g., elevator rails, curtain walls, and doors)). It is noted that all results are far below 0.2 percent limit value for all cases and seismic intensity levels.

Nevertheless, the residual storey drift value can be a good indicator for self-centering capacity of the adopted systems. In this regard, using composite links may provide better centering capacity than the bare steel link under MCE level. Furthermore, using HCW system produces significant self-centring capacity compared with the conventional shear wall system under DBE and MCE levels. 
Table 3 - Mean values of residual storey drifts percent

\begin{tabular}{cccc}
\hline & TR=475 years & TR=2475 years & TR=9975 years \\
\hline RC wall & 0.014 & 0.067 & 0.142 \\
\cline { 2 - 4 } HCW-TSCB & 0.010 & 0.035 & 0.156 \\
\cline { 2 - 4 } HCW-RSCB & 0.008 & 0.039 & 0.144 \\
HCW-RCCB & 0.008 & 0.035 & 0.144 \\
\hline
\end{tabular}

\section{FRAGILITY ANALYSIS}

Fragility assessment has usually been used for performance-based earthquake purposes in order to predict the probability of exceedance of structural damage as a function of earthquake motion intensity. Generally, the damage level in certain structural element or whole structure is expressed by a damage index like element rotation value or IDR (inter storey drift). The approach to describe motion intensity is usually accomplished by using ground motion indices, such as PGA (peak ground acceleration), peak ground velocity or spectral acceleration at the fundamental period of the building, $\mathrm{S}_{\mathrm{a}}(\mathrm{T} 1)$. In accordance with the fact that fragility curve formation using $\mathrm{S}_{\mathrm{a}}(\mathrm{T} 1)$ measure is more efficient than PGA; and allows lower limit of uncertainty when assessing the drift response (Iervolino and Manfredi) [44], it will be employed in this study.

To build fragility curves, there is a necessity to clearly determine damage states, which are defined as threshold levels of damage sustained by structural components. To this end, the damage states that are defined by the FEMA P-58 for slender RC shear walls [45] and links in the EBFs [46] will be used to express corresponding damage state of RC wall piers and typical steel coupling beams. The demand parameter of typical links is taken as plastic link rotation, whereas for slender RC wall, the demand parameter will be expressed by effective wall drift as defined by FEMA P-58[45]. In case of very short replaceable steel links, the damage parameter is total link rotation and the damage states that are concluded from the tests performed by Ji et al. 2017[47]. In the case of composite links, the basic segment is imposed to be the steel link and the concrete part damage will not be taken into account. Based on Shayanfar et al. [27] results, where concrete portion does not affect damage sequence of the steel link; the same fact is supposed to be true in the situation of this research. Subsequently, the similar damage parameter and damage states of the very short steel link will be adopted for the case of the composite link.

In order to provide fragility data of RC slab above the RSCB element, the parameters suggested by Ji. et al. 2017 [47] will be used for HCW-RSCB and HCW-RCCB cases. Since there is no data in the literature about the slab fragility in case of using long links (HCWTSCB), it will not be considered in this study. However, the RC slab in such case seems to suffer minimal damage when be compared with other cases because of low rotation demand values obtained in coupling beams. Table 4 provides a summary of the median values, dispersions related to the $\mathrm{RC}$ wall and links fragility, damages description and associated repair methods. 
Fragility curves produced in this investigation rely on lognormal cumulative distribution, the mathematical relation of fragility function is reported in Eq.2

$F(D)=\Phi\left(\frac{\ln (D / \theta)}{\beta}\right)$

Where $\mathrm{D}$ is demand parameter. $\Phi$ is cumulative lognormal function. $\theta$ is median of damage limit states. $\beta$ is the logarithmic standard deviation. It involves the participation of record-torecord demand variability and the uncertainty related to component capacity.

The resulting fragility curves are plotted in Figures 20-23 for all aforementioned limit states. The links are numbered based on storey number.

Table 4 - Structural elements fragility data

\begin{tabular}{|c|c|c|c|c|c|c|}
\hline \multirow{2}{*}{$\begin{array}{l}\text { Structural } \\
\text { component }\end{array}$} & \multirow{2}{*}{$\begin{array}{c}\text { Damage } \\
\text { state }\end{array}$} & \multirow{2}{*}{$\begin{array}{c}\text { Damage } \\
\text { parameter }\end{array}$} & \multicolumn{2}{|c|}{ Fragility data } & \multirow{2}{*}{$\begin{array}{c}\text { Damage } \\
\text { discerption }\end{array}$} & \multirow{2}{*}{ Repair method } \\
\hline & & & Median & Dispersion & & \\
\hline \multirow{4}{*}{ Wall } & DS1 & \multirow{4}{*}{$\begin{array}{l}\text { Effective } \\
\text { wall drift }\end{array}$} & $\begin{array}{c}0.118 \\
\text { percent }\end{array}$ & 0.762 & $\begin{array}{l}\text { Formation of } \\
\text { initial cracking. }\end{array}$ & Cosmetic repair \\
\hline & DS2 & & $\begin{array}{c}0.927 \\
\text { percent }\end{array}$ & 0.476 & $\begin{array}{l}\text { Spalling of } \\
\text { concrete cover }\end{array}$ & $\begin{array}{l}\text { Inject cracks with } \\
\text { epoxy and replace } \\
\text { finishes }\end{array}$ \\
\hline & DS3 & & $\begin{array}{c}1.28 \\
\text { percent }\end{array}$ & 0.341 & $\begin{array}{l}\text { Exposure of } \\
\text { longitudinal wall } \\
\text { reinforcement }\end{array}$ & $\begin{array}{c}\text { Patch spalled } \\
\text { concrete, epoxy } \\
\text { inject } \\
\text { cracks and replace } \\
\text { finishes }\end{array}$ \\
\hline & DS4 & & $\begin{array}{c}1.86 \\
\text { percent }\end{array}$ & 0.441 & $\begin{array}{l}\text { Crushing of } \\
\text { concrete }\end{array}$ & $\begin{array}{c}\text { Replacement of the } \\
\text { wall or concrete } \\
\text { jacketing }\end{array}$ \\
\hline \multirow[b]{2}{*}{ Long link } & DS2 & \multirow{2}{*}{$\begin{array}{l}\text { Plastic } \\
\text { rotation } \\
(\mathrm{rad})\end{array}$} & 0.010 & 0.58 & $\begin{array}{l}\text { Flange local } \\
\text { buckling }\end{array}$ & Heat straightening \\
\hline & DS3 & & 0.018 & 0.48 & $\begin{array}{c}\text { Flange fracture or } \\
\text { Lateral torsional } \\
\text { buckling }\end{array}$ & Link replacement \\
\hline \multirow{3}{*}{$\begin{array}{l}\text { Very Short } \\
\text { Link }\end{array}$} & DS1 & \multirow{3}{*}{$\begin{array}{l}\text { Total } \\
\text { rotation } \\
(\mathrm{rad})\end{array}$} & 0.05 & 0.3 & $\begin{array}{c}\text { Substantial slab } \\
\text { damage }\end{array}$ & $\begin{array}{c}\text { Cosmetic repair or } \\
\text { Injection of epoxy } \\
\text { or Replacement of } \\
\text { the local slab above } \\
\text { the RSCB }\end{array}$ \\
\hline & DS2 & & 0.09 & 0.19 & $\begin{array}{l}\text { Buckling of the } \\
\text { web or flanges in } \\
\text { the shear link }\end{array}$ & $\begin{array}{l}\text { Heat straightening } \\
\text { buckled elements or } \\
\text { replacement of } \\
\text { shear link. }\end{array}$ \\
\hline & DS3 & & 0.11 & 0.15 & $\begin{array}{l}\text { Facture of the } \\
\text { web in the shear } \\
\text { link or fracture of } \\
\text { the link flange-to- } \\
\text { end plate welds. }\end{array}$ & Link replacement \\
\hline
\end{tabular}




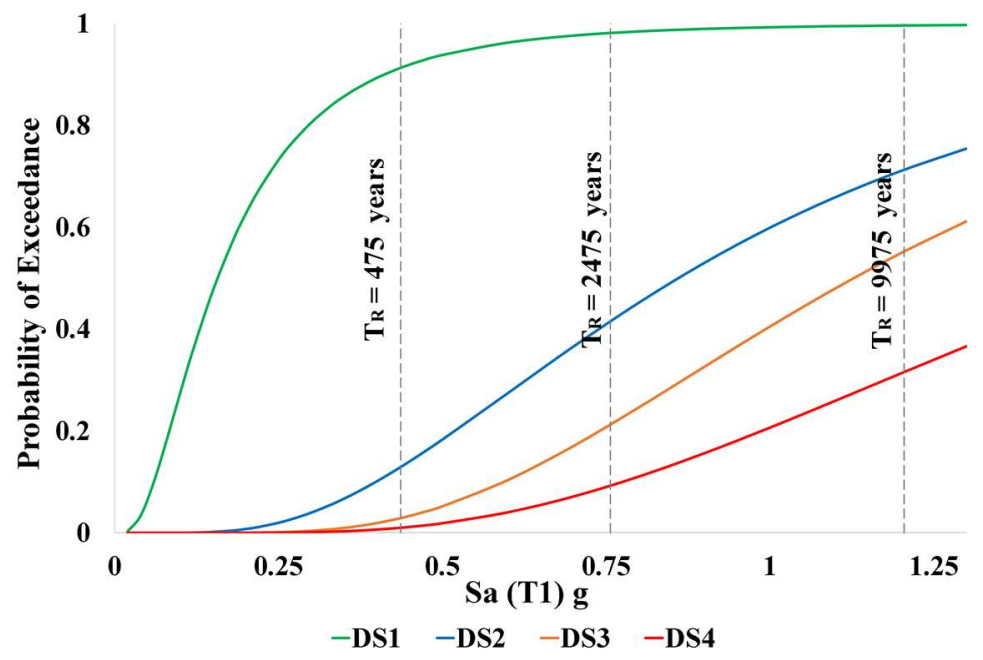

Fig. 20 - Fragility curves of the wall of $R C$ wall case

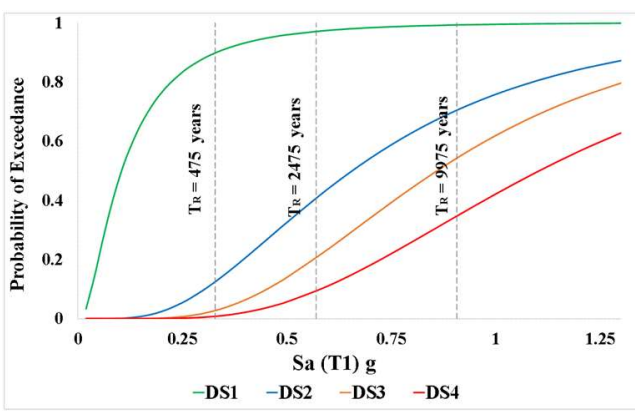

(a)

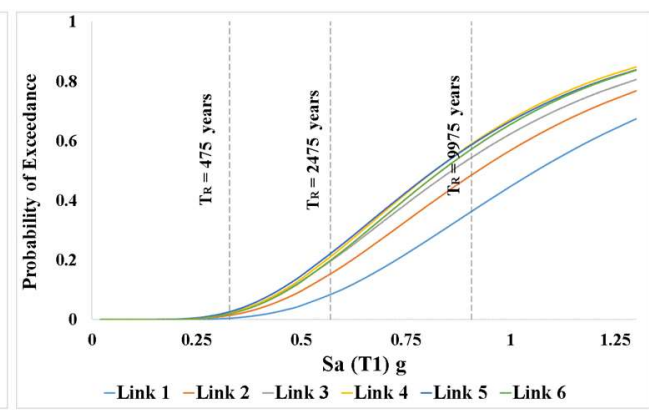

(b)

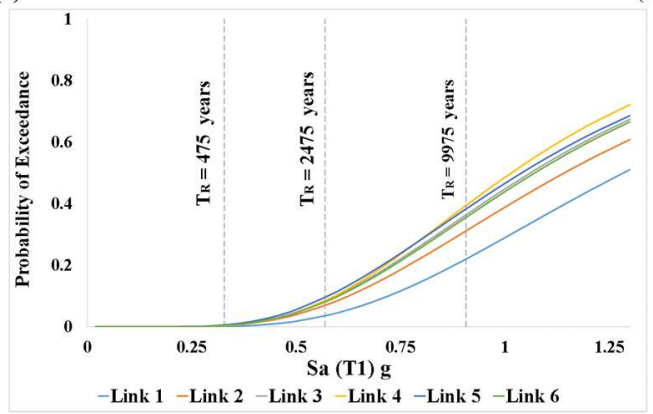

(c)

Fig. 21 - Fragility curves for HCW-TSCB case: (a) Wall piers (b) DS2 performance level for all links (c) DS3 performance level for all links 


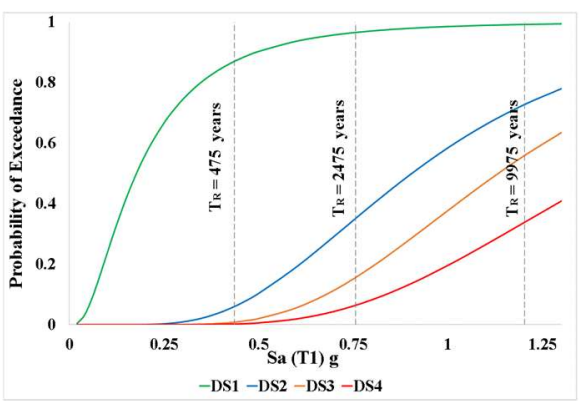

(a)

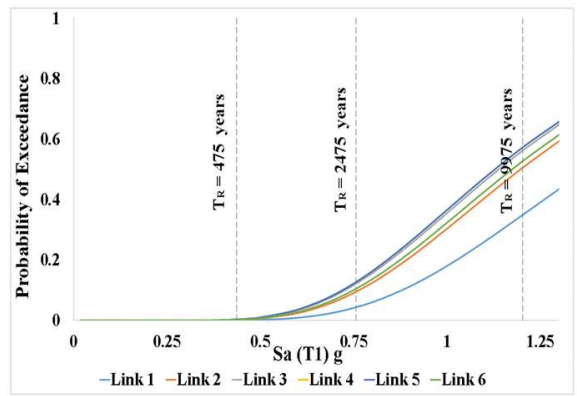

(c)

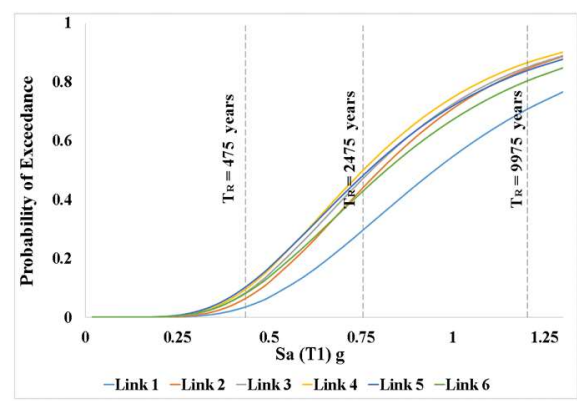

(b)

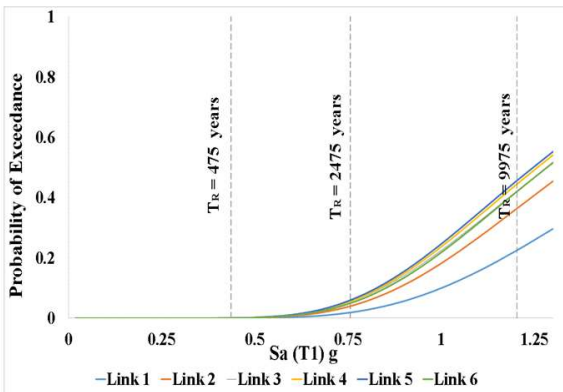

(d)

Fig. 22 - Fragility curves for HCW-RSCB case: (a) Wall piers (b) DS1 performance level for all links (c) DS2 performance level for all links (d) DS3 performance level for all links

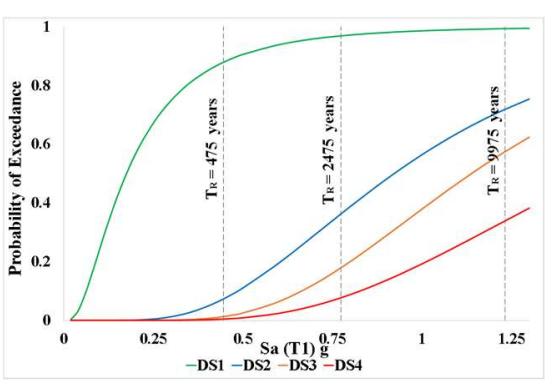

(a)

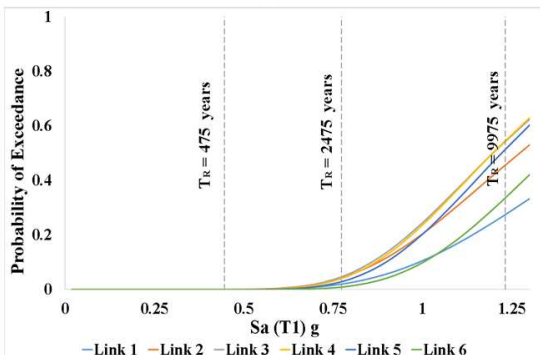

(c)

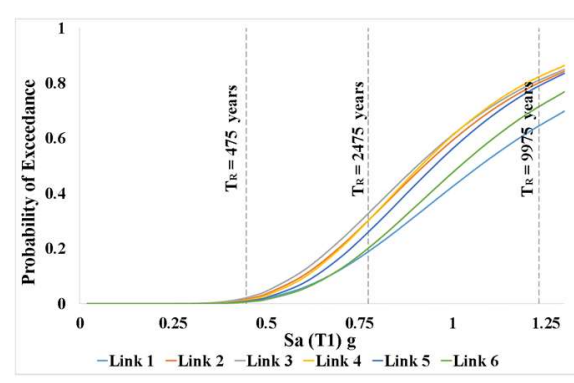

(b)

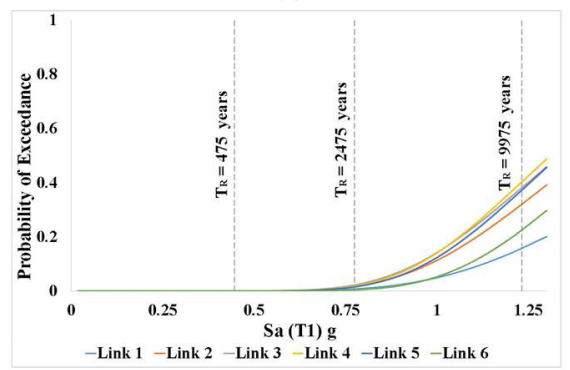

(d)

Fig. 23 - Fragility curves for HCW-RCCB case: (a) Wall piers (b) DS1 performance level for all links (c) DS2 performance level for all links (d) DS3 performance level for all links 
In order to explain thoroughly fragility results and produce clear comparison between the case studies, the probability of exceedance will be determined at fixed values of the three earthquake intensity levels for all structural components and damage states. The results are plotted in Fig. 24,25 .

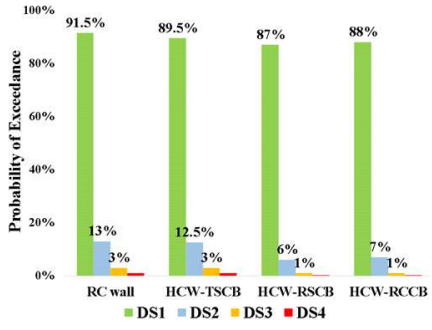

(a)

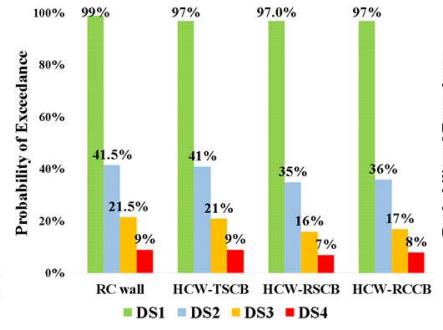

(b)

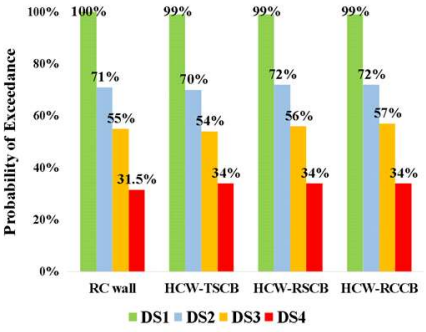

(c)

Fig. 24 - Probability of exceedance for wall damage states: (a) 475 years level, (b) 2475 years level, (c) 9975 years level

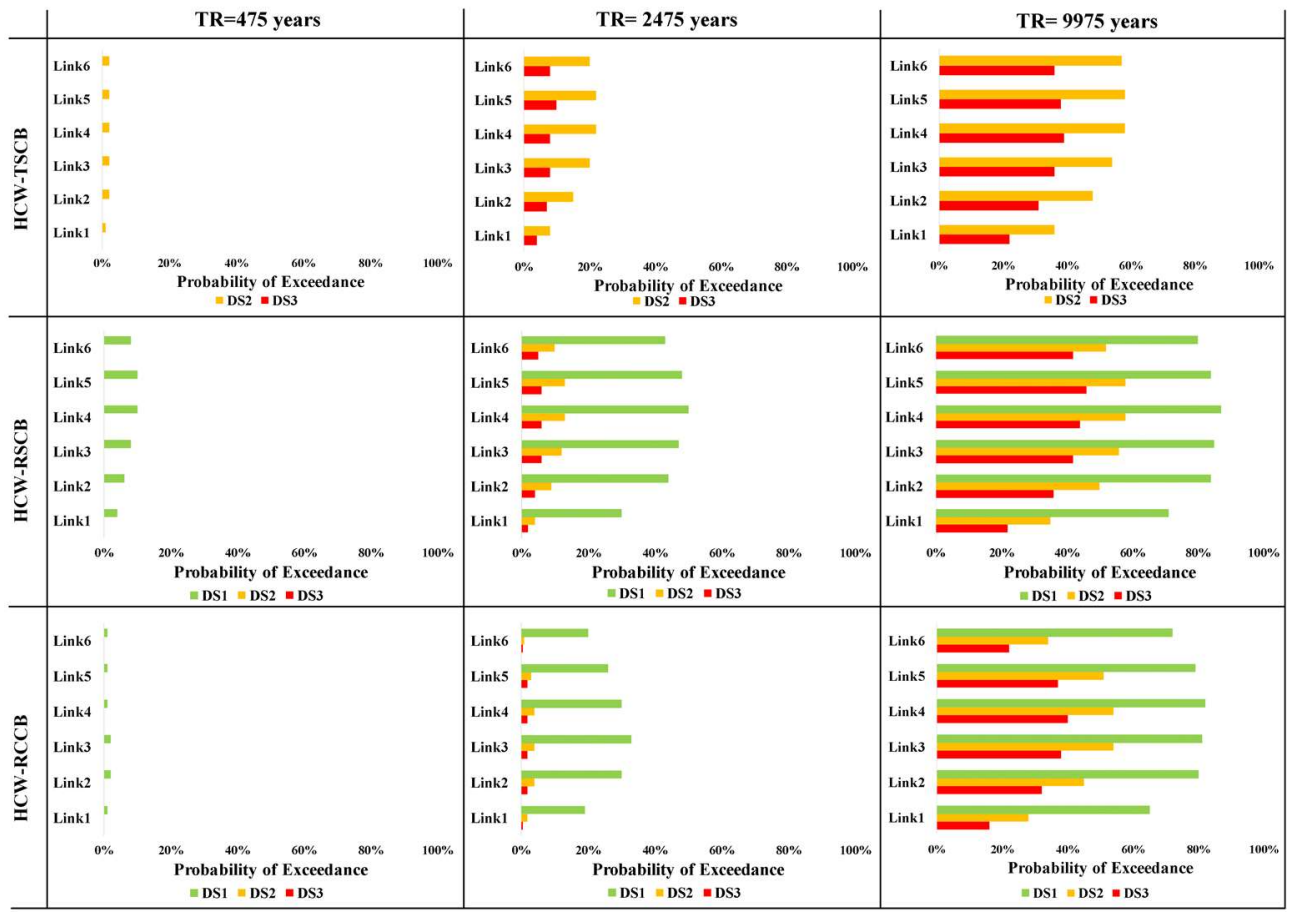

Fig. 25 Probability of exceedance for the damage states of all links 
Fig. 24 indicates higher damage levels for $\mathrm{RC}$ wall piers in moderate-rise buildings than had been shown for high-rise buildings by Ji. et al. [23]. Using typical steel coupling beam does not show high improvement in damage resistance of $\mathrm{RC}$ wall piers when compared to the stiff conventional RC wall system. However, expected damage to all walls under DBE and MCE levels is limited to cracks or slight spalling of concrete. Under VRE level, exposure of longitudinal wall reinforcement and crushing of concrete may be confidently expected for both the $\mathrm{HCW}$ and the conventional RC wall. Using replaceable steel coupling beams shows lower values of vulnerability in RC wall piers under DBE and MCE levels. Despite the higher energy dissipation of composite links, their impact is not noted in RC wall piers. Under VRE level, all cases show a relatively similar behaviour.

In contrast to RC wall fragility data, the level of damage in links between the cases is not convergent. In accordance with Fig. 25, it is observed that all the cases indicate a limited probability of damage in links under DBE level.

- In regard to RC slab fragility, using reinforced concrete infill can achieve 83 percent, 40 percent and 7 percent lower damage probability than using steel stiffeners under DBE, MCE and VRE levels, respectively.

- Under MCE level, replaceable steel links case can achieve 43 percent and 35 percent lower damage probability than typical coupling beams case for DS2 and DS3, respectively. Using reinforced concrete infill (HCW-RCCB) presents acceptable improvement against using steel stiffeners (HCW-RSCB) with 40 percent reduction for buckling of the web damage state and 44 percent reduction for web facture damage state. The upper links in composite links case demonstrate an evident reduction in damage amount compared with middle links.

- In the case of VRE level, the variation between the performances of links is minimized. Replaceable steel links case shows very limited reduction in damage probability at DS2 level and 15 percent increase in damage probability in DS3 level compared with typical coupling beams case. Using reinforced concrete infill presents 14 percent damage reduction in buckling of the web damage state and 23 percent reduction in web facture damage state compared with using the steel stiffeners.

\section{CONCLUSIONS:}

This study attempts to gain more insight into the (HCW) hybrid coupled wall system when different potentials of coupling beams are utilized. These possibilities include using typical steel coupling beam and the replaceable steel coupling beam (RSCB) proposed by Ji. et al.[22]. Furthermore, a novel composite shear link is proposed and modelled using the OpenSees platform by employing reinforced concrete infill rather than steel stiffeners in the inner space of steel link. A comparison with stiff bare RC wall system shows similar initial stiffness and flexural strength capacity as the HCW system with RSCB case is also carried out. An attempt has been made to accurately assess the dynamic response and to present a quantitative estimation of vulnerability of the wall and links for each case. It is assumed that all of which have identical wall pier configurations and CR coupling ratio equals 0.4 . The main conclusions are listed below:

-Using reinforced concrete infill instead of steel stiffeners proves similar lateral displacement demand values and vulnerability in wall piers. However, this method does not require extra 
design detailing for walls and foundations. The essential advantage of this method is the high efficiency to preserve upper RC slab and steel links maintenance than using steel stiffeners. It can achieve 40 percent lower damage probability for RC slab and steel links under the maximum credible earthquake level (MCE) compared with using the steel stiffeners.

- The RSCB case presents the least lateral displacement demand under DBE level. For extreme seismic levels, the RSCB case start behaving similar to typical steel coupling beams case. However, the RSCB method can attain 35 percent reduction in links fracture probability compared with typical steel coupling beams case under MCE seismic level. But it causes higher damage in links than typical steel coupling beams case under VRE seismic level.

- The typical steel coupling beams illustrate poor performance in terms of lateral displacement restriction at DBE level, but behaves well under extreme seismic events.

-The stiff bare RC wall reveals high lateral displacements demand for both DBE and MCE levels, whereas in terms of VRE level it has similar behaviour as other cases.

These outcomes give designers the required database to make the decision in regard of the method of construction due to their particular architectural and constructional considerations.

\section{Symbols}

$\begin{array}{ll}\mathrm{A}_{\mathrm{w}} & : \text { Web area of the expanded beam } \\ \mathrm{CR} & : \text { Coupling ratio } \\ \mathrm{D} & : \text { Demand parameter } \\ \mathrm{e} & : \text { Link length } \\ \mathrm{e}_{\mathrm{s}} & : \text { Critical length of short links } \\ \mathrm{e}_{\mathrm{L}} & : \text { Critical length of long links } \\ \mathrm{fc} & : \text { Concrete compressive strength } \\ \text { fy } & : \text { Yield stress of steel } \\ \mathrm{G} & : \text { Shear modulus } \\ \mathrm{K}_{0} & : \text { Initial stiffness } \\ \mathrm{L} & : \text { Lever arm between the centroids of the wall piers } \\ \mathrm{l}_{\mathrm{b}} & : \text { Total overturning moment resisted by the wall piers } \\ \mathrm{LM} & : \text { Plastic resistant moment of link } \\ M_{\mathrm{p}} & : \text { Behaviour factor } \\ \mathrm{q} & : \text { Spectral acceleration } \\ \mathrm{Sa} & : \text { Return period of the earthquake } \\ \mathrm{TR} & : \text { Shear force of the beam } \\ \mathrm{V}_{\mathrm{beam}} & \end{array}$




$\begin{array}{ll}V_{\mathrm{p}} & : \text { Plastic resistant shear of link } \\ \beta & : \text { Logarithmic standard deviation } \\ \theta & : \text { Median of damage limit states } \\ \Phi & : \text { Cumulative lognormal function } \\ \mathrm{EBF} & : \text { Eccentrically braced frame system } \\ \mathrm{DBE} & : \text { Design basis earthquake } \\ \text { DCM } & : \text { Medium ductility class } \\ \text { DS } & : \text { Damage state } \\ \text { HCW } & : \text { Hybrid coupled wall } \\ \text { IDA } & : \text { Incremental dynamic analysis } \\ \text { MCE } & : \text { Maximum credible earthquake } \\ \text { PEER } & : \text { Pacific Earthquake Engineering Research } \\ \text { PGA } & : \text { Peak ground acceleration } \\ \text { RCCB } & : \text { Replaceable composite coupling beam } \\ \text { RCW } & : \text { Reinforced concrete wall } \\ \text { RSCB } & : \text { Replaceable steel coupling beam } \\ \text { TSCB } & : \text { Typical steel coupling beam } \\ \text { V-EBF } & : \text { Eccentrically braced frames with vertical link } \\ \text { VRE } & : \text { Very rare earthquake } \\ \end{array}$

\section{References}

[1] Harries, K.A., Gong, B., Shahrooz, B.M., Behavior and design of reinforced concrete, steel, and steel-concrete coupling beams, Earthquake Spectra, 16, 4, 775-800, 2000.

[2] El-Tawil, S., Harries, K.A., Fortney, P.J., Shahrooz, B.M., Kurama, Y., Seismic design of hybrid coupled wall systems: state of the art, Journal of structural engineering, 136, 7, 755-69, 2010.

[3] Hajjar, J.F., Composite steel and concrete structural systems for seismic engineering, Journal of Constructional Steel Research, 58, 5-8, 703-23, 2002.

[4] Harries, K.A., Mitchell, D., Cook, W.D., Redwood, R.G., Seismic response of steel beams coupling concrete walls, Journal of Structural Engineering, 119, 12, 3611-29, 1993.

[5] Park, W.-S., Yun, H.-D., Seismic behaviour of coupling beams in a hybrid coupled shear walls, Journal of Constructional Steel Research, 61, 11, 1492-524, 2005.

[6] Shahrooz, B.M., Remmetter, M.E., Qin, F., Seismic design and performance of composite coupled walls, Journal of Structural Engineering, 119, 11, 3291-309, 1993. 
[7] El-Tawil, S., Kuenzli, C.M., Pushover of hybrid coupled walls. II: Analysis and behavior, Journal of Structural Engineering, 128, 10, 1282-9, 2002.

[8] El-Tawil, S., Kuenzli, C.M., Hassan, M., Pushover of hybrid coupled walls. I: Design and modeling, Journal of Structural Engineering, 128, 10, 1272-81, 2002.

[9] Fortney, P.J., Shahrooz, B.M., Rassati, G.A., Seismic performance evaluation of coupled core walls with concrete and steel coupling beams, Steel and Composite Structures, 7, 4, 279-301, 2007.

[10] Gong, B., Shahrooz, B.M., Steel-concrete composite coupling beams-behavior and design, Engineering Structures, 23, 11, 1480-90, 2001.

[11] Gong, B., Shahrooz, B.M., Concrete-steel composite coupling beams. I: Component testing, Journal of Structural Engineering, 127, 6, 625-31, 2001.

[12] Gong, B., Shahrooz, B.M., Concrete-steel composite coupling beams. II: Subassembly testing and design verification, Journal of Structural Engineering, 127, 6, 632-8, 2001.

[13] Gong, B., Shahrooz, B.M., Gillum, A.J., Cyclic response of composite coupling beams, Special Publication, 174, 89-112, 1998.

[14] Harries, K.A., McNeice, D.S., Performance-based design of high-rise coupled wall systems, The Structural Design of Tall and Special Buildings, 15, 3, 289-306, 2006.

[15] Harries, K.A., Mitchell, D., Redwood, R.G., Cook, W.D., Nonlinear seismic response predictions of walls coupled with steel and concrete beams, Canadian Journal of Civil Engineering, 25, 5, 803-18, 1998.

[16] Shahrooz, B.M., Deason, J.T., Tunc, G., Outrigger beam-wall connections. I: component testing and development of design model, Journal of Structural Engineering, 130, 2, 253-61, 2004.

[17] Shahrooz, B.M., Gong, B., Tunc, G., Deason, J.T., An overview of reinforced concrete core wall-steel frame hybrid structures, Progress in Structural Engineering and Materials, 3, 2, 149-58, 2001.

[18] Shahrooz, B.M., Tunc, G., Deason, J.T., Outrigger beam-wall connections. II: subassembly testing and further modeling enhancements, Journal of Structural Engineering, 130, 2, 262-70, 2004.

[19] Doran, B., Polat, Z., A proposal for estimation of coupling beam stiffness of shear walls, IMO,Teknik Dergi, 10, 3, 1973-82, 1999.

[20] Fortney, P.J., Shahrooz, B.M., Rassati, G.A., Large-scale testing of a replaceable "fuse" steel coupling beam, Journal of structural engineering, 133, 12, 1801-7, 2007.

[21] Christopoulos, C., Montgomery, M., Viscoelastic coupling dampers (VCDs) for enhanced wind and seismic performance of high-rise buildings, Earthquake Engineering \& Structural Dynamics, 42, 15, 2217-33, 2013.

[22] Ji, X., Wang, Y., Ma, Q., Okazaki, T., Cyclic behavior of replaceable steel coupling beams, Journal of Structural Engineering, 143, 2, $04016169,2017$. 
[23] Ji, X., Liu, D., Sun, Y., Molina Hutt, C., Seismic performance assessment of a hybrid coupled wall system with replaceable steel coupling beams versus traditional RC coupling beams, Earthquake Engineering \& Structural Dynamics, 46, 4, 517-35, 2017.

[24] Standardization, E.C.f., Euro Code 8: Design of structures for earthquake resistancepart 1: general rules, seismic actions and rules for buildings, Brussels: European Committee for Standardization, 2005.

[25] Ji, X., Wang, Y., Ma, Q., Okazaki, T., Cyclic behavior of very short steel shear links, Journal of Structural Engineering, 142, 2, 04015114, 2016.

[26] Kanz, R., Schneider, B., Bouwkamp, J., Results and correlative analysis of a composite two storey eccentric braced frame, Earthquake Engineer 10th World, 3441, 1992.

[27] Shayanfar, M., Barkhordari, M., Rezaeian, A., Experimental study of cyclic behavior of composite vertical shear link in eccentrically braced frames, Steel \& Composite Structures, 12, 1, 13-29, 2012.

[28] Bosco, M., Marino, E.M., Rossi, P.P., Modelling of steel link beams of short, intermediate or long length, Engineering structures, 84, 406-18, 2015.

[29] Zona, A., Dall'Asta, A., Elastic-plastic model for steel buckling-restrained braces, Journal of Constructional Steel Research, 68, 1, 118-25, 2012.

[30] Mazzoni, S., McKenna, F., Scott, M.H., Fenves, G.L., OpenSees command language manual, Pacific Earthquake Engineering Research (PEER) Center, 264, 2006.

[31] ABAQUS, A.u.s.M.V., ABAQUS, Inc., Dassault Systèmes,USA, 2018.,

[32] Sun, G., Chuang-Sheng, W.Y., Gu, Q., DesRoches, R., An effective simplified model of composite compression struts for partially-restrained steel frame with reinforced concrete infill walls, Earthquake Engineering and Engineering Vibration, 17, 2, 403$15,2018$.

[33] ASCE Task Committee on Design Criteria for Composite Structures in Steel and Concrete, Guidelines for design of joints between steel beams and reinforced concrete columns, Journal of Structural Engineering, 120, 8, 2330-57, 1994.

[34] Mander, J.B., Priestley, M.J., Park, R., Theoretical stress-strain model for confined concrete, Journal of structural engineering, 114, 8, 1804-26, 1988.

[35] Denavit, M.D., Hajjar, J.F., Leon, R.T. Seismic behavior of steel reinforced concrete beam-columns and frames. In: Structures Congress 2011, pp. 2852-61, 2011.

[36] Paulay, T., Priestley, M.N., Seismic design of reinforced concrete and masonry buildings, 1992.

[37] Lu, X., Xie, L., Guan, H., Huang, Y., Lu, X., A shear wall element for nonlinear seismic analysis of super-tall buildings using OpenSees, Finite Elements in Analysis and Design, 98, 14-25, 2015.

[38] Ji, X., Sun, Y., Qian, J., Lu, X., Seismic behavior and modeling of steel reinforced concrete (SRC) walls, Earthquake Engineering \& Structural Dynamics, 44, 6, 955-72, 2015. 
[39] Saatcioglu, M., Razvi, S.R., Strength and ductility of confined concrete, Journal of Structural engineering, 118, 6, 1590-607, 1992.

[40] Kent, D.C., Park, R., Flexural members with confined concrete, Journal of the Structural Division, 1971.

[41] OpenSees Wiki. Steel02 Material-Giuffré-Menegotto-PintoModel with Isotropic Strain

Hardening.http://OpenSees.berkeley.edu/wiki/index.php/Steel02_Material_Giuffr percentC3 percentA9-MenegottoPinto_Model_with_Isotropic_Strain_Hardening [Accessed on 2019].

[42] PEER, N. Pacific Earthquake Engineering Research Center NGA Database. 2011.

[43] ATC. Seismic Performance Assessment of Buildings Volume 1-Methodology (FEMA P-58-1). Applied Technology Council: Redwood City, CA, 2012.

[44] Iervolino, I., Manfredi, G. A review of ground motion record selection strategies for dynamic structural analysis. In: Modern Testing Techniques for Structural Systems, Springer, 2008, pp. 131-63.

[45] Birely, A.C., Lowes, L.N., Lehman, D.E., Fragility Functions for Slender Reinforced Concrete Walls (FEMA P-58/BD-3.8.9), Federal Emergency Management Agency, Washington, DC, 2011.

[46] Gulec, C.K., Gibbons, B., Chen, A., Damage States and Fragility Functions for WShape Steel Link Beams in Eccentrically Braced Frames (FEMA P-58/BD-3.8.5), Federal Emergency Management Agency, Washington, DC, 2010.

[47] Ji, X., Wang, Y., Zhang, J., Okazaki, T., Seismic behavior and fragility curves of replaceable steel coupling beams with slabs, Engineering Structures, 150, 622-35, 2017. 
